\title{
WOMEN CHANGE EVERYTHING ${ }^{1}$
}

\author{
MARY A. YEAGER
}

This address urges a more self-aware business history. It uses autobiographical details and select biographies of literary figures and women professionals to shed light on the subtle and not-so subtle inequalities associated with business and capitalism. The deliberate tease in the title-WOMEN CHANGE EVERYTHING-is intended to convey the power of word placement to change interpretive meaning and significance, and the power of history to modify understanding. Modifiers are key to an appreciation of the constraints and opportunities that have framed the lives and experiences of women in economies and societies. Even footnotes function in this address as modifiers, uncannily revealing sources of authorial intent and inspiration and throwing light on literary and historiographical hierarchies.

I suspect that few business historians will be surprised to learn that a woman who has been tagged "106 percent feminist" intends to

(C) The Author 2015. Published by Cambridge University Press on behalf of the Business History Conference.

doi:10.1017/eso.2015.72

Mary A. Yeager is President of the Business History Conference. E-mail: yeager@ ucla.edu.

1. Some credit for the choice of title goes to reformer activist Naomi Klein, who uses the vague noun identifier, "this," to capture the complex processes of climate change, This Changes Everything: Capitalism Versus The Climate (New York: Simon \& Schuster, Kindle edition 2014). I position WOMEN as a noun to stress women's agency. The spacing between words in the title is deliberate. I follow the lead of two literary lights who underscored the significance of word placement in grappling with meaning. In A Room of One's Own, Virginia Woolf was asked to speak about women and fiction. She penned this reply: "The title women and fiction might mean ... women and what they are like; or it might mean women and the fiction that they write; or it might mean women and the fiction that is written about them; or it might mean that somehow all three are inextricably mixed together." (Quoted by Robert A. Colby, in a review of three books in NineteenthCentury Fiction, Vol. 39, No. 3[Dec., 1984], 339). T.S. Eliot thought word placement important enough to write a poem about it. In "Little Gidding" he writes of "every phrase and sentence that is right [...]where every word is at home, taking its place to support the others ... the complete consort dancing together." (Quoted by Sam Leith, Financial Times, "Much to learn from Yoda, public speakers still have," June 9, 2015, p. 12.) 
deliver a presidential address titled WOMEN CHANGE EVERYTHING. The "Yeager Grumble" has acquired brand status. By now, it's practically a litany: "What about women? Where are the women? Does nothing ever change?"2

Yet the title "Women Change Everything" did not come naturally, even to this self-identified feminist. ${ }^{3}$ For me, "inequalities" have been more an everyday life-puzzle than a life-long intellectual project. I was raised on two farms, one in the South Dakota badlands and another in Montana, where cattle outnumbered people and the buffalo still roamed. ${ }^{4}$ Life lessons abounded. When my method of ditch irrigation flooded a ten-acre wheat field and my decision to sunbathe

2. The late David Jones, a Montana preacher's son, tradesman, and carpenter, explained the $106 \%$ during a casual conversation, August 2014, Rollins, Montana: "That seemed just about right" he quipped, "for an over-educated daughter of a Montana farmer."

3. Some scholars insist that women and men, in their capacities as historical actors or observers, must self-identify with feminism in order to earn the label. I grant the historian interpretive and analytical leeway to make a persuasive case, one way or another, based on sources and context. Thus, a woman or man might resist the label and yet embrace or undermine the goals of feminism, depending on how feminism is conceptualized, experienced, and understood. Historically, the word "feminism" has usually provoked modifiers, often more negative than positive. Helen E. Archdale, “The Women's International Movement in Relation to General Internationalism," The Australian Quarterly 20, no.4 (December 1948), p. 17, notes that Webster's International Dictionary, 1927, defined feminism as "The theory, cult and practice of those who hold that present laws, conventions and conditions of society prevent the free and full development of woman, and who advocate such changes as will do away with undue restrictions upon her political, social and economic conduct and relations; also the propaganda for assuring these changes." H. W. Fowler's Modern English Usage, 1940, defined feminism as "Faith in Women; Advocacy of Rights of Women; Prevalence of Female Influence." For an analysis, see especially, Karen Offen, "Defining Feminism: A Comparative Historical Approach, Signs 14, no.1 (1988), 119-157 (http://www.jstor.org/stable/3174664).

4. Moviegoers, if not Montana buffalo lovers, might recall watching "Where the Buffalo Roam," the semi-biographical 1980 Universal Studio film, based loosely on the life of gonzo journalist Hunter S. Thompson, and starring Bill Murray and Peter Boyle. Buffalo found Montana a refuge after being nearly wiped out in the early 1800s by a government-supported hunting campaign. South Dakota actually boasts a higher cattle-per-person ratio than Montana. Ray Yeager's choice of South Dakota as the site of his first farm, and the timing of his move to Montana, mattered. According to rough estimates of data from the United States Census of Agriculture: 1945: General Report, Vol. II, Ray Yeager would have been one of nearly 69,000 farmers in South Dakota in 1945, where all farm land accounted for about 43 million acres. The average value of farms (land and buildings) equaled $\$ 11,124$. The average acreage per farm of all land in farms in South Dakota in 1945 was about 626 acres. Yeager's farm size is not known, but data on South Dakota farms in the 1940s suggest that more than half the farms were between 100 and 500 acres in size. Given that mom and dad singlehandedly ran the farm, that average size seems likely. Farms of more than 1000 acres accounted for about 10 percent of the total. Montana, by contrast, 
while driving tractor ripped out a fence line, I learned that issues of "equality" hardly mattered. ${ }^{5}$

As a test of gender equality, this farm experiment was definitely rigged. It was tied to physique and brute strength, and was administered by my father, a free farmer patriarch who used the results to underscore what he considered to be women's natural subordination to men. I dared not contradict. Evidence did not lie. A younger, bigger brother got the family farm, not through inheritance but by going into debt: His farm income provided yearly annuities to keep our parents afloat in old age. ${ }^{6}$

Who could argue with such an outcome? In such a world, I was not fit to be a farmer. Early on I realized that no amount of bulking up or hulking up was likely to place me on an equal footing with Brother George. ${ }^{7}$

hosted 40,000 farmers in 1945, but farmland accounted for nearly 60 million acres (p. 21). The average acreage per farm of all land in farms in Montana in 1945 was 1,557 acres (p. 73). Montana in 1945 had far more big farms of more than 10,000 acres (777) than did South Dakota in 1945 (254) (p. 102). But, South Dakota farmers at least suffered far fewer crop failures than did Montana around the same time (p. 38).

5. Inequalities framed the battle for water rights. See the report of Chief of Irrigation Investigations, Elwood Mead, Irrigation Institutions: Discussion of The Economic And Legal Questions Created By The Growth Of Irrigated Agriculture In The West (New York and London: Macmillan, 1910), especially the discussion of Montana, 297-308. A more recent history of ditch irrigation in the Snake River Valley of Idaho and Washington state is Mark Fiege, Irrigated Eden: The Making of an Agricultural Landscape in the American West (Seattle: University of Washington Press, 1999).

6. Families have long played a central role in women's perceptions of life and society, and they have been theorized about by scholars for centuries, for better and worse. Some see families as nurturing love nests, others as snakepits of competitiveness. They are both. The varieties are infinite and ever-changing. In positioning the adjective "farm" before "family," I signal a type of family peculiar in its rural-ness, perhaps, but reflecting a common 1950s patriarchal structure with structural inequalities of gender and sex. How familial interactions shape a family member's identity and understanding of power inequities is the subject of a large literature. One text that captures the multiple cross-cutting tensions of familial life in the context of changing economies and societies is Ulrich Beck and Elisabeth Beck-Gernsheim, The Normal Chaos of Love, translated by Mark Ritter and Jane Wiebel (Frankfurt, Germany: Polity Press, 1995, 1999, 2002, 2004 reprint), esp. 1-44, "Love or Freedom: Living Together, Apart or At War," which situates the family historically in the center of the gender struggle. For a dyspeptic view of gender struggles inside contemporary families, see feminist Alison Wolf, The XX Factor: How the Rise of Working Women Has Created a Far Less Equal World (New York: Crown Publishers, Random House, 2013).

7. The argument about physical strength and gender differences still rages on, especially in press coverage of the military. For one contemporary female military officer's view of gender differences, see "Lt.Col. Kate Germano on the 
I was fit for the life of a farmer's wife, but it didn't fit me. My mother filled that role as competently as Dad did his, with the requisite blend of feistiness and fealty: She defied him and deferred to him in unequal measure. As the youngest of five sisters and three brothers hailing from a cotton-farming family in Butler, Oklahoma, Mom knew the value of both sisterhood and homemaking. As a girl she dreamed of being a legal secretary and a honky-tonk piano player, but she kept those dreams to herself. ${ }^{8}$

Married to my workaholic dad, she toiled alongside him, even as his ambitions stretched beyond the farm. A hailstorm demolished our South Dakota farm, ${ }^{9}$ but before he started another he built the first drive-in theater in Conrad, Montana. ${ }^{10}$ Mom enlisted sisters,

Marines and Women,” New York Times, July 28, 2015 (http://atwar.blogs.nytimes. com/2015/07/28/lt-col-kate-germano-on-the-marines-and-women/?smid=nytcoreipad-share\&smprod=nytcore-ipad). A historically informed analysis is Joshua Goldstein, War and Gender: How Gender Shapes the War System and Vice Versa (Cambridge: Cambridge University Press, 2003), esp. 59-102, which examines the historical record of female combatants, gender differences in anatomy and physiology, and the role of female military leaders. Gender analysis has uncovered a strong historical association between masculine traits such as physical strength and the alleged superiority of men and everything masculine in patriarchal culture, including business firms. Michael Roper, Masculinity and the British Organization Man Since 1945 (Oxford and New York: Oxford University Press, 1994, reprinted 2003), 105-132, explores the cult of toughness. R. W. Connell, Masculinities (Berkeley and Los Angeles: University of California Press, 2nd ed., 1995, 2005), shows how manual workers define masculinity through heavy labor. Gail Bederman, Manliness And Civilization: A Cultural History of Gender and Race in the United States, 1880-1917 (Chicago: University of Chicago Press, 1995), focuses on two women and two men, showing how each of them in different ways interprets and applies notions of masculinity in different contexts, linking ideas about strength and manliness to issues of race, class, and power. An explicit focus on physical strength emerges in the literature on nursing, especially with the entry of males into the nursing profession. See Joan Evans, "Men Nurses: A Historical and Feminist Perspective," Journal of Advanced Nursing 47 (2004): 321-328 (doi: 10.1111/j.1365-2648.2004.03096.x) and the medical technical analysis offered by A. E. Miller, J. D. MacDougall, M. A. Tarnopolsky and D. G. Sale, "Gender Differences in Strength and Muscle Characteristics," European Journal of Applied Physiology and Occupational Physiology, 66, no. 3 (1991): 254262, U.S. National Library of Medicine, National Institutes of Health, http://www. ncbi.nlm.nih.gov/pubmed8477683, accessed September 4, 2015

8. Butler, in central southwest Oklahoma, emerged after the Cheyenne-Arapaho Reservation was opened for non-Indian settlement in 1892. Linked by rail, the town became a support center for local farmers who grew cotton, broomcorn, and wheat. Linda D. Wilson, "Butler,” Encyclopedia of Oklahoma History and Culture, www. okhistory.org (accessed September 5, 2015).

9. According to the National Centers for Environmental Information, National Oceanic and Atmospheric Administration Overview, hail caused the most crop damage in 1950, and South Dakota in particular was one of the hardest-hit states. See Most Harmful Weather Events between 1950 and 2011, https://rstudio-pubs-static. s3.amazonaws.com/49534_a54f210244d9464.

10. Ray Yeager's Star Drive In theater opened in August 1952. Neither timing nor location were ideal. As the site of an outdoor theater, Conrad lagged twenty 
in-laws, nieces, nephews, and all three of her children for the project, coordinating the "chicken sandwich brigade" to stock the theater's concession stand. It was a thriving community enterprise that was suspended only once, when Montana winds blew the screen down, and was halted nearly a decade later after being bought out by better capitalized local rivals from Shelby, Montana, who also invested in Conrad's indoor Orpheum theater. ${ }^{11}$

My father's unlikely job resume left me with mismatched roots in both farming and entertainment. I did not have to become a student of $\mathrm{Al}$ Chandler to learn that no two industries were alike. The movie and farm businesses were as different as the landscapes of Hollywood and Montana. Mother Nature dared farmers to dream. Moviemakers turned dreams into money. My own dreams ranged even further. I pictured myself an Olympic gold medalist; a solo concert clarinetist; a singer in an acid rock band; a news anchorwoman; and a translator for the United Nations. I even dreamed of marrying a movie star.

years behind Riverton (now Camden), New Jersey, where Richard Hollingshead, the son of the owner of Whiz Auto Products Company, built America's first drive-in theater in 1932. "Wives Beware" was its first showing. Other Montana towns hosted outdoor movie theaters either earlier than Conrad or around the same time that Yeager launched his family enterprise. Lewistown, Montana, erected its first drive-in theater in 1944, followed by Deer Lodge, 1950; Plentywood, 1952; Libby, 1954; and Terry, 1955, Conrad was a small farming town of about 1900 people in 1950. Yet the entire state-which boasted a population density of just 6 people per square mile-was home to 39 drive-in cinemas by the late 1950s. Yeager's drive-in had a capacity of about 150 cars, the average for most drive-ins. (For information about Montana theaters from driveinmovie. com, webcraft by virtualities, for New Jersey theaters see www.umich.edu/ drivein/theater.html, University of Michigan; United Drive-In Theaters Association (UDITOA).

11. For information about the Star Drive In, see Conrad Independent Observer, August 5, 1952. For details on the history of the indoor Orpheum Theater in Conrad, see Cinema Treasures, accessed August 10, 2015 (http://cinematreasures.org), and Conrad Area Chamber of Commerce, accessed August 10, 2015. When constructed in 1918, the Orpheum Theatre of Conrad was allegedly designed to be on par with state-of-the-art theaters in larger cities, such as Great Falls, Billings, and Butte. Conrad's theater included an orchestra that accompanied the opening night's silent film. The history is unclear whether this theater was part of the Orpheum Circuit, a chain of vaudeville and movie theaters, founded in 1886 and operated until 1927, when it merged with the Keith-Albee theater chain, ultimately becoming part of the Radio-Keith-Orpheum (RKO) corporation. Environmental historians might be interested to know that during the time of the theater's revonvation in the 1990s, a mountain of coal ash was discovered in the dirt cellar. There is speculation that the first owners failed to remove the coal in the furnace, preferring to spread the burnt ash and pour water over it. Also found were a real estate agent's cardboard boxes full of bluish business records, along with dozens of antique glass Coca-Cola syrup bottles (Cinema Treasures, http://cinematreasures.org, accessed August 10, 2015). In the 1950s, Theo Martin Kluth and Herbert Kluth of Shelby, Montana-a small town just 20 miles to the north of Conrad-purchased Ray Yeager's Drive-In and Conrad's Orpheum Theater. Theo Martin Kluth had worked as an 
In farm country, I learned the differences between real men and "Economic Man," that badly miscast character whom Frank Knight called "the frictionless machine of economic mechanics."12 My father was hardly frictionless. Farming didn't allow for that. In the face of a crisis he would weigh available information, he would guess what others were going to do, he would decisively act, and he would pray.

I watched with the eyes of a farm girl, learning more than I ever realized. There was no competitive equilibrium on family farms. ${ }^{13}$ Gender as performance trumped gender as an analytical tool. Tools were useless if they could not work the earth. Methods and theories were only as good as the assumptions on which they were built. I was no young Sylvia Thrupp, but I grasped instinctively the wisdom of her advice to historians years earlier: "Any medieval peasant who ever sold a cow could have told [you] as much or more about the forces of supply and demand as was to be learned from nineteenth century theory." Theory was no match for farm work, and life was seldom fair. ${ }^{14}$

Needless to say, I never dreamed in those days of becoming a business historian. Who among us did? But these life lessons in business did teach me that the business of "self-making" was going to be an ongoing project, neither easy nor automatic. In my teen years, the terms I used to evaluate and understand behavior were not fully formed. Inequalities of resources, asymmetries of sex, and patriarchal power were of little concern. That Big Montana Sky was an equalizing force. Everyone looked small under that vast dome. I sensed that I was capable of achieving almost anything that didn't demand the physical strength of a gorilla. ${ }^{15}$

usher and cashier at Shelby, Montana theaters in her youth, and after marrying Herbert Kluth in 1936, the couple invested and managed an aviation service, the First State Bank of Shelby, Par Oil Company, and Kluth farms. Herbert Kluth died in 1950, and sometime during the 1950s Theo Martin Kluth organized as Kluth, Inc., and invested in the Orpheum Theater. In 1960, Theo married a prominent Shelby banker, Rulon Bartschi. Theo Martin Kluth Bartschi was instrumental in organizing Interstate Amusements, Inc., in Twin Falls, Idaho, and remained active in the familycontrolled businesses, serving as vice president and chairman of the board of the First State Bank. Kluth, Inc. sold out to Larry Flesch of Shelby in the 1970s. For details on the Kluth family, see Cut Bank Pioneer Press (cbpress@bresnan.net), Golden Triangle News, Obituaries, October 30, 2002, accessed on the web August 10, 2015.

12. Quoting Frank Knight, "Imperfect Competition," The Journal of Marketing, Vol. 3, No. 4 (1939): 366.

13. Margaret Levenstein, Presidential Address, "Escape from Equilibrium: Thinking Historically About Firm Responses to Competition," Enterprise \& Society 13,no.4 (2012):1-9(http://muse.edu/journals/enterprise_and_society/v013/13.4. lev...4/8/2014).

14. Sylvia Thrupp, "The Role of Comparison in the Development of Economic Theory," Journal of Economic History 17, no. 4 (1957): 554-570.

15. Self-making depends on learning and self-knowledge about what is learned. Janice McCabe, "What's In a Label? The Relationship between Feminist SelfIdentification and 'Feminist' Attitudes among U.S. Women and Men," Gender \& 
But capabilities, as Amartya Sen has reminded us, are nothing without the resources needed to achieve them. ${ }^{16}$ I played the clarinet well enough to be crowned Queen of the Canadian Legion Band Festival, ${ }^{17}$

Society 19, no. 4 (2005): 480-505 (http://222.jstor.org/stable/30044613, accessed: 07/04/2014). A pioneering and now classic assessment of the self-making of several notable male entrepreneurs is Pamela Walker Laird, Pull: Networking and Success since Benjamin Franklin (Cambridge, MA and London: Harvard University Press, 2006). The link between self-making and female entrepreneurship, with a focus on Hetty Green, is explored in Susan Yohn, "Crippled Capitalists: The Inscription of Economic Dependence and the Challenge of Female Entrepreneurs in NineteenthCentury America," Feminist Economics 12, no. 1-2 (2006), 85-109 (http://dx. doi.org/10.1080/13545700500508270); Regina Casteleijn-Osomo, "Comparing Sense-Making of Identities of Mompreneurs in Malta and Finland,” entrepreneurship master's thesis, Department of Management and International Business, Aaito University School of Business (http://urn.fi/URN:NBN:fi:aalto-201403171577); Jane Greenway Carr, “'We Must Seek on the Highways the Unconverted': Kathryn Magnolia Johnson and Literary Activism on the Road," American Quarterly 67, no. 2 (2015): 443-470 (doi: 10.1353/aq.2015.0020). Sociologists, anthropologists, labor historians, and political economy have focused more on labor and the workplace. Rebecca Prentice, “No One Ever Showed Me Nothing': Skill and Self-Making among Trinidadian Garment Workers," Anthropology \& Education Quarterly, 43, no. 4 (2012): 400-414 (http://www.jstor.org/stable/23359077); Gina A. Ulysse, Downtown Ladies: Informal Commercial Importers in Jamaica: A Haitian Anthropologist and Self-Making in Jamaica (London and Chicago: University of Chicago Press, 2010), reviewed by Heather A. Horst, Journal of the Royal Anthropological Institute 15, no. 3 (2009): 643-644 (http://www.jstor.org/stable/40541716); Dorinne K. Kondo, Crafting Selves: Power, Gender, and Discourses of Identity in a Japanese Workplace (Chicago: University of Chicago Press, 1990).

In my own case, self-identification as a feminist took work, experience and learning. Intellectual guidance came from Amartya Sen, Identity and Violence: The Illusion of Destiny (New York: W. W. Norton, 2007). Sen argues that the task of acquiring self-awareness and an identity is never a static development, but ongoing, a product of intellect and emotions, of personality and background, of historical context and psychological predispositions, of a willingness to fight for beliefs associated with equality and justice for women in ways that are recognized by others. Self-making is a lifelong puzzle. Self-knowledge is never so secure that it cannot be questioned, at least in the face of situations that demand adaptation.

The extent to which life on the farm nurtured my feminism is still unclear to me. I find it difficult to disentangle the personal from the professional; life on the farm from the education that enabled my exit from farm life; and entry into academia and the professions, which embodied and reinforced gender biases as well. Scholars of the early women's movement did not neglect agriculture or agrarianism as a seedbed of feminism, but those studies never gained traction among the scholarly elite based in large urban centers and elite educational centers. Nevertheless, scholars have continued to grapple what has been called "agrarian feminism." See Georgina M. Taylor, “'Ground for Common Action’: Violet McNaughton’s Agrarian Feminism and the Origins of the Farm Women's Movement in Canada," Ph.D. dissertation, Carleton University, September 18, 1997.

16. Bina Agarwal, Jane Humphries, Ingrid Robeyns, eds., Amartya Sen's Work And Ideas: A Gender Perspective (New York: Routledge, 2005). Humphries' scholarship in economic history, particularly that involving debates about women's roles and wages in the Industrial Revolution, is notable for its contribution to gender and feminist analysis.

17. The band festival was held in Lethbridge, Alberta, a town incorporated in 1892 and established as a city in 1906, named after William Lethbridge, president of 
but I never played Carnegie Hall; I did a passable impersonation of Dean Martin at Montana Girls' State, but no one ever mistook me for Janice Joplin. ${ }^{18}$ I was the runner-up debater in a state forensics competition, but I came nowhere near to filling the big Montana shoes of native son Chet Huntley. ${ }^{19}$ I mastered Latin well enough to ride in a chariot as Queen of the National Junior Classical League, but the UN translator's job was beyond my reach. ${ }^{20}$ Latin, I discovered, was not a spoken language.

Some dreams, of course, come true. I did marry a movie star.

Why, you might ask, am I talking so much about myself? This is, after all, a presidential address at an academic conference. There are

the North Western Coal \& Naviation Co. Beginning in the 1880s, with a production of “The Pirates of Penzance," town boosters, including a later established Lethbridge Music Club, nurtured and sustained a musical tradition that included several allfemale groups that won national and international recognition, among them the Glee Singers, Teen-Clefs, and the Anne Cambell Singers. (www.thecanadianencyclopedia. en/article/lethbridge-alta-emc/, article by Philip M. Wults, Margaret Nelson, 02/07/06, last edited 12/07/13).

18. Notable biographies of Joplin and other female rock stars include Alice Echols, Sweet Scars of Paradise; The Life and Times of Janis Joplin (New York: Metropolitan Books/Henry Holt, 1999); Patti Smith, Just Kids (New York: Harper Collins, 2010). For insights into the sexism and inequalities in the rock music business, there is no better starting point than feminist rock critic Ellen Willis, especially Nona Willis Aronowitz, ed., The Essential Ellen Willis (Minneapolis/ London: University of Minnesota Press, 2014), which includes Willis's contributions to Janis Joplin, “The Rolling Stone Illustrated History of Rock 'n'Roll, 1980.”

19. Chet Huntley, a plain-speaking reporter, was born in Cardwell, Montana, the son of a telegraph operator for the Northern Pacific Railway. In the 1960s, Huntley also became involved with a New York advertising agency, Levine, Huntley, Schmidt, Plapler \& Beaver, where he earned a 10 percent share in the agency in return for putting his name on the agency letterhead and attending some agency meetings. He also owned a cattle farm in Stockton, New Jersey, which he promoted under his name before NBC raised conflict of interest and promotional concerns. The Big Sky Resort in Bozeman, Montana, is also a Huntley creation. See his memoir, The Generous Years: Remembrances of a Frontier Boyhood (New York: Random House, 1968). Details: Wikipedia.

20. UN translators were initially a privileged, predominantly male group, drawn from war-ravaged areas, speaking multiple languages. Only much later did women gain a foothold. See Helen Reynolds-Brown, "How I Became a UN Interpreter;” see interview by Louise Tickle, May 15, 2014, The Guardian, www.theguardian.com/, accessed September 2, 2015; David Zweig, Invisibles: The Power of Anonymous Work in an Age of Relentless Self-Promotion (Portfolio/Penguin, 2014, Kindle), considers UN translators among the most important and least visible workers in the world (businessinsider.com, accessed September 2, 2015).

My dreams of being a translator for the UN were built on shaky foundations of high school Latin, the only (dead) language offered at Conrad Public High School. However, those dreams were nourished by a professor at Middlebury College, Neil Harris, who taught Latin by speaking it. Until my sophomore year in college, I intended to become a scholar of classical Latin and Greek. The National Junior Classical League, organized in 1936, had branches in Montana, whose members included aspiring students of the classical languages. 
perilous risks to a scholar's reputation in promiscuously sharing her biographical details in this forum. ${ }^{21}$ But as I set out to fashion tonight's address, I found that biography-my own and that of several other women-aggressively pushed its way into my field of vision. By now, I have come to see biography as a framework for my remarks with the potential to illuminate my current thoughts on "Inequalities," the grand theme of our conference, not to mention the happy winners and the hapless losers in business.

I gleaned one insight into the uses of biography when I did a quick review of past presidential addresses. Of the Association's thirty-two male presidents, many chose to blithely weave personal details into their chosen topics. One historian whose topic was the faceless managers of managerial capitalism chose the surprising title, "A Personal Experience." Another introduced a loveable Galambosian clan that later reappeared in his book The Creative Society. Another, with a poetical bent, offered up a Shakespearean sonnet on the subject of "Dad and the TVA." Another entertained the crowd with a dramatization of “...Business History As Human Activity." Yet another boldly applied his own unique personal touch: He delivered no address at all. ${ }^{22}$

But beginning in the mid-1990s I noticed that things began to change. Priorities seemed to subtly shift. Presidential addresses took on a little more sobriety and gravitas. Autobiographical self-mockery went missing. Schedules were even altered to place the speeches before rather than after the traditional wine-soaked presidential banquet. I began to wonder: Was there a connection here? Did this gradual change in tone have anything to do with the growing number of women in our organization and in the office of president?

Certainly something was at work. Of the five women who have preceded me as president, nearly all downplayed their own life stories to sharpen their focus on how decision makers, owners, innovators, firms, and competitors act in history. Few references were heard on the large subject of gender. Indiana's Irene Neu stood out ever so slightly: As the 1985 president, she dutifully tipped her hat to the struggles of the women's movement before excavating the biographical details of the lives and fortunes of three businessmen. ${ }^{23}$

21. The risks are not confined to scholars. Sheryl Sandberg confesses that she was cautioned not to speak out or to share autobiographical details or complaints about sexism or gender biases in the workplace. Sheryl Sandberg (with Nell Scovell), Lean In: Women, Work, and the Will to Lead (New York: Alfred A. Knopf, 2013), $10,67,145$.

22. In order: Alfred D. Chandler, Lou Galambos, Thomas McCraw, Morton Rothstein, Glenn Porter.

23. I relied on the archived list of presidential addresses, beginning in 1972. (The list before 1972 has not yet been compiled for online viewing.) In order of their election: Irene Neu, "My Nineteenth-Century Network: Erastus Corning, 
Our reflexive disdain for the biographical may just be a function of our impatience with subjective back stories. "This is so, but does it matter?" we cry. "What if it weren't? Would it make any difference?" Business historians have been distancing themselves from biography since the 1940s, when company biographies had become the field's defining feature and weighty albatross. Two recent surveys of the state of the field fail to even mention biography or explore its methodological possibilities as critique. ${ }^{24}$

Benjamin Ingham, Edmond Forstall," Business and Economic History, 2nd Series, Vol. 14 (1985): 1-17; Mira Wilkins, "Business History as a Discipline," Business and Economic History, 2nd Series, Vol. 17 (1988): 1-7; Naomi Lamoreaux, "Reframing the Past: Thoughts About Business Leadership and Decision-making Under Uncertainty," Enterprise \& Society 2.4 (Dec. 2001): 632 -659; JoAnne Yates, "How Business Enterprises Use Technology: Extending the Demand-Side Turn," Enterprise \& Society 7.3 (Sept. 2006): 422-455; Pamela Laird, 2008, "Looking Toward the Future: Expanding Connections for Business Historians," Enterprise \& Society 9.4 (Dec. 2008): 575-590; Margaret Levenstein, "Escape from Equilibrium: Thinking Historically about Firm Responses to Competition," Enterprise \& Society 13.4 (Dec. 2012): 710-728. Another analytical angle is the extent to which gender also factors into presidential nominations: Do BHC members nominate regardless of sex/gender? Or, do they nominate scholars of their own sex more often? If this is so, what accounts for it? Do the nominations suggest the importance of networks? Value to the organization? Topics of interest? Even before the 2015 meetings ended, there were several conversations with members who playfully urged my consideration of a male nominee as the next president. Were they implying that we female presidents were disadvantaging qualified others (i.e., males?), that nominations should now rotate to equalize opportunities for men?

24. Abe de Jong, David Michael Higgins, and Hugo van Driel, "Towards a New Business History?" Business History, 57, no. 1 (2015): 5 -29, http://dx.doi.org/10. 1080/00076791.2014.977869, accessed June 7, 2015; Andrew Popp, "History, a Useful 'Science' for Management: A Response," Enterprise \& Society 10.4 (2009): 831-836, and the response by Eric Godelier, "History, a Useful 'Science' for Management? From Polemics to Controversies," Enterprise \& Society 10, no. 4 (2009): 791-806; Mary O’Sullivan and Margaret B. W. Graham, "Guest Editors' Introduction, 'Moving Forward by Looking Backward: Business History and Management Studies,"' Journal Of Management Studies 47, no. 5 (2010): 775-790, do not mention biography except insofar as they critique antiquated company histories, but they urge greater self-reflection on the part of historians: "In ordinary times neither historians nor management theorists are especially prone to selfreflection. When they write about historiography, historians often write histories of historiography!" (p. 788). They cite as "enlightening and provocative" (p. 788) Telling the Truth of History by UCLA colleagues Joyce Appleby, Lynn Hunt, and Margaret Jacob. I found the format of a presidential address especially suited to self-reflection and to the task of reflecting on the lives and challenges facing other professional women. Biographies of businessmen and biographies of companies came to be regarded by a second generation of business historians as problematic and antiquated because of their narrowness and subjectivity. For a pioneering contemporary look at gender and racial issues associated with black economic empowerment in South Africa, which uses biography if not biographical method, see Stephanie Decker, "Postcolonial Transitions in Africa: Decolonization in West Africa and Present Day South Africa, Journal of Management Studies 47, no. 5 (2010): 791-813 (doi: 10.1111/j.1467-6486.2010.00924x). 
Nor has such disdain of biography been limited to scholars of business. It remains undervalued across the social sciences. No less a figure than Sigmund Freud expressed his doubts about biography in a letter to Arnold Schweig in 1936: "To be a biographer you must tie yourself up in lies, concealments, hypocrisies. ... [B]iographical truth is not to be had, and even if it were to be had we could not use it." Adam Phillips seconded the motion. To him, Freud's unconscious forces made deterministic readings of cause and effect impossible. As he put it, "A biography, like a symptom, fixes a person in a story about themselves." 25

But biography is not just about a person. Capitalism, like feminism, is generating its own biographies, which reveal a wide range of properties, traits, biases, and inequalities. Only three nights ago, at this very conference, Ariane Daguin told her own story, spinning off a hundred details of the complex workings of the competitive business of fine food purveying. As moral philosopher Mary Midgely proclaimed, "Understanding someone's character, through seeing the patterns of motivation and emotional response in his or her life-story, is as vital to human survival as understanding how to make crops or fireone cannot be substituted for the other. ... What makes a clock tick is different than what makes a person tick." Feminist philosopher Nancy Fraser, whose most recent intervention privileges the ideas of redistribution, recognition, and representation, shares with Midgely a desire to understand capitalism not only as an economic system, but also as a form of life. ${ }^{26}$

25. See the review of Adam Phillips' Becoming Freud: The Making of a Psychoanalyst by Talitha Stevenson, Financial Times, May31/June1 2014, 11.

26. Ariane Daguin, opening plenary speaker of the BHC/EBHA conference, Miami, Florida, June 24, 2015. Daguin is CEO of D’Artagnan, a corporate purveyor of fine meats and foie gras, based in Newark, New Jersey. David Midgley, ed., The Essential Mary Midgley, (London and New York: Routledge, Kindle ed., 2005), quoting Mary Midgley, 17. Nancy Fraser, Hanne Marlene Dahl, Pauline Stoltz and Rasmus Willig, "Recognition, Redistribution and Representation in Capitalist Global Society: An Interview with Nancy Fraser," Acta Sociologica Vol. 47, No. 4 (Dec. 2004): 374-382. (http://www/jstor.org/stable/4195051) Accessed 19 May 2014, 128.97.244.130.

Autobiography + biography $=$ more women + more female voices, which ultimately leads to a gendered business history capable of addressing asymmetries of sex and power as well as a host of other inequalities. Women's historians and literary scholars have made a persuasive case for biographical method as a tool to explore the lives, perceptions, thoughts, and experiences of women. On biography and the link to women's history see Susan Ware, "Writing Women's Lives: One Historian's Perspective,” Journal of Interdisciplinary History, 40, No. 3 (2010): 413-435, (http://muse.jhu.edu/journals/jih/summary/v040/40.3.ware.html, access by UCLA Library, August 31, 2015). Ware argues that "no other field has demonstrated the symbiotic connection between biography and history better than the study of women and gender” (p. 413). Lois W. Banner, “AHR Roundtable: Biography 
Mary Wollstonecraft grappled with these issues two hundred years before. A late eighteenth-century literary iconoclast, Wollstonecraft was an avatar of early feminism. Writing in the 1790s, she unabashedly made herself "the hero of her own tale." In her 1797 Letters from Sweden, she insisted, "A person has a right... to talk of himself" [emphasis added]. The use of that small, grammatically correct pronoun lays bare the difficulties Wollstonecraft faced when she wanted to talk about herself. As biographer Charlotte Gordon explained, "Mary

as History," American Historical Review 114, no. 3 (2009): 579-586, discusses biographical method as a scholarly and a teaching tool. She notes that biography was embraced by pioneering women historians in the 1970s: "[W]e stressed the importance of uncovering the life stories of women forebears to serve as role models to define ourselves and our careers in a in a male-dominated, masculinized profession” (p. 579). Ellen C. Dubois, "Eleanor Flexner and the History of American Feminism," Gender \& History 3, No. 1(Spring 1991), 81-90, illuminates the struggles that Flexner encountered as she began to publish about women. Flexner was especially disappointed with the reception to her biography of Wollstonecraft. Dubois emphasizes that anti-feminist attacks instensified after World War II. She cites, in particular, the work of Ferdinand Lundberg and Marynia F. Farnham, Modern Woman: The Lost Sex (New York: Harper \& Brothers Publishers, 1947), who castigated Wollstonecraft as a "classic neurotic, an unhappy woman displacing her personal failures onto a misguided indictment of 'society' for 'wronging' her sex."

Given the male-dominated business world and more social-science leaning professions, including management, economics, science, engineering, it may be regretted but not surprising that business historians who have embraced biography have focused on predominately male-owned and -managed firms and male business leaders and/or professionals and academics. Exemplary as histories and biographies are the contributions of the late Thomas M. McCraw, especially Prophet of Innovation: Joseph Schumpeter and Creative Destruction (Cambridge, MA, and London: Belknap Press of Harvard University Press, 2007), Prophets Of Regulation: Charles Francis Adams; Louis D. Brandeis; James M. Landis; Alfred E. Kahn (Cambridge, MA.: Belknap Press, Harvard University, 1984), The Founders And Finance: How Hamilton, Gallatin, And Other Immigrants Forged A New Economy (Cambridge, MA and London: Belknap Press of Harvard University Press, 2012). Model collective biographies include Andrej Svorencik, "MIT'S Rise to Prominence: Outline of a Collective Biography," Center for the History of Political Economy, Duke University, Working Paper No. 2013-19, revised January 2014; Harro Maas, "Making Things Technical: Samuelson at MIT," Center for the History of Political Economy, Duke University, Working Paper No. 2014-01, January 2014. The business school professoriate has also seen the advantages of biography in teaching leadership. See Boas Shamir, Hava Dayan-Horesh and Dalya Adler, "Leading by Biography: Towards a Life-Story Approach to the Study of Leadership," Sage 1, no. 1 (2003): 13-29, who suggest that "the telling of a life story is itself a leadership behavior. Leadership is a highly involving role in the sense that the role and the self are relatively undifferentiated. In other words, leaders are persons for whom the identity of a leader is a central and important part of their self-concepts, and for whom the exercise of the leadership role is a form of self-expression." If one applies gender to this discussion, some obvious problems emerge, especially given that cultures have constrained women far more than men from narrating their own histories, and men have far outnumbered women as leaders. 
knew only too well, women were not supposed to place their experience at the center of any narrative, fictional or otherwise." 27 Virginia Woolf may have known, but she didn't care. "For most of history," she caustically declared, "Anonymous was a woman." 28

I caught a mild dose of this Woolfian fever. Biography intruded as I struggled to relate women to inequalities, as they related to the intertwined histories of business and capitalism. ${ }^{29}$ Inequality forced renewed consideration of what Margaret Atwood has so colorfully described as those "ancient balances," which include notions of fairness, reciprocity, equivalences, and values. It is a topic that, in important ways, has defined the realities of most women's lives throughout the world and across a range of institutions, including households, families, and business organizations. Donning a historian's hat, Atwood reminds us that

27. Charlotte Gordon, Romantic Outlaws: The Extraordinary Lives Of Mary Wollstonecraft and Her Daughter Mary Shelley (New York: Random House, 2015), 516, quoting Wollstonecraft in an advertisement for Letters from Sweden.

28. http://www.goodreads, Virginia Woolf, "For most of history, Anonymous was a woman." According to Wikiquote, the "anonymous" quote is inaccurate. Woolf actually wrote: "I would venture to guess that Anon, who wrote so many poems without signing them, was often a woman." Ch. 3 (p. 51), A Room Of One's Own (https://en.wikiquote, last modified 25 July 2015).

29. The problem is that much of the old and new literature on business and capitalism overrides women as active change agents. Even Sven Beckert's prize-winning Empire of Cotton (New York: Alfred A. Knopf, Random House LLC, lst edition Kindle), which contains more than 130 references to women, includes women primarily as part of a subordinated labor force-which, of course, they were. But, a reliance upon a growth-enhancing, capitalist-industrial, commodity-oriented framework is, in my opinion, part of the problem, one that obscures as much as it illuminates the political, social, and cultural processes underpinning structural and gender inequalities. Jane Austen is one of the few female voices in Thomas Piketty's Capital, where women's role as growth promoters is limited to their role in reproduction.

I ask: Whose understanding and definition of business and capitalism is to be privileged? N. S. B. Gras, the pioneering father of business history, published Business and Capitalism: An Introduction to Business History (New York: F. S. Crofts \& Co., 1939) as a teaching tool. He defined capitalism broadly as "a system of getting a living through the use of capital, which in turn we may regard as goods or trained abilities used in producing other goods or services." Then, as was his wont, he added this dispeptic observation: "the term 'capitalism,' like 'rheumatism' and 'indigestion,' must be abandoned or differentiated. To be sure, discrimination in the use of the term impairs its propaganda value. Our interest here, however, lies simply in a better understanding of the subject" (p. vii). He presumes that men will "naturally", save, invest, venture, plan, work, and achieve. Women, on the other hand, go unmentioned except as raw material for sneering symbolism. His efforts to analyze capitalism betray a conscious or an unconscious strain of misogyny and sexism. "The profit motive is a prolific mother of deformed children," he writes, "but, there are other women with ugly offsprings" (p. 311).

What about the voices of women? How have they understood and defined business and capitalism? Gras's research associate, Henriette M. Larson, has reminded 
"after several thousand years of rigorous misogyny, during which gods replaced goddesses and women were subordinated and downgraded, the female justice figures persisted." She poses a piquant question: "Why does Justice continue to wear a dress, at least in western tradition?"30

Such questions haunted me in ways that I didn't expect. Emotions challenged intellect. I could not resolve the historical tensions between such opposites as fairness and unfairness, equality and inequality, reciprocity and selfishness, and the presence and absence of opportunities and outcomes. I had a stake in this history, not only by virtue of my sex and gender, but also because of my status as a historian of business and of women. Serving as both historical subject and object forced me to explore what I most cared about. And what I most cared about were the moral and intellectual presumptions of economic life. ${ }^{31}$

Big questions arose: How have economies and cultures interacted to frame our ideas of individuality, gender, sex, and race? Are business historians equipped to link humanistic conceptions and personal life to economic experience? How have they come to understand the claims that women have made about their roles in their personal and professional lives? How have they integrated the cultural and economic components of women's new ambitions? ${ }^{32}$

My small story suggests a larger purpose. I embrace biography as part of a collective and ongoing enterprise. It is an enterprise that salutes some of the women who have colored my thinking about inequalities, business, and capitalism. In so doing, I offer a perspective based on my own intellectual journey, tapping into two intersecting research streams.

us, "Business history [and, by extension, capitalism] is not a onetime discovery ... it did not spring full blown from Professor Gras' brow" (Larson Family Archives, St. Olaf, Northfield, MN). Ayn Rand defined capitalism as "the only system that answers yes to the question, is man free?", and "a social system based on the recognition of individual rights, including property rights, in which all property is privately owned" (Capitalism: The Unknown Ideal [New York: Signet, Penguin, 1967], 10). Or consider Naomi Klein's understanding of "capitalism as industrialism, which promised liberation from nature," in This Changes Everything, 10.

30. Margaret Atwood, Payback: Debt and the Shadow Side of Wealth (Toronto: House of Anansi Press Inc., 1st ed., Publishers Group West, Berkeley, CA, 2008), 35.

31. These thoughts and the questions below were provoked by Theodore $\mathrm{M}$. Porter's illuminating biography of the nineteenth-century Victorian and eccentric, father of the correlation coefficient, Karl Pearson: The Scientific Life in a Statistical Age (Princeton, NJ: Princeton University Press, 2004), vii, 4-9. Pearson argued that the subordination of women promoted the egoism of men, thereby weakening feminism while strengthening anti-feminism (Porter's interpretation, 126). One source of inspiration was Mary Wollstonecraft, as evidenced by Pearson's contribution to: "The Woman's Question: Being a Paper Read at the Preliminary Meeting of the Wollstonecraft (?) Club," July 11, 1885, (Porter reference, footnote \#7, 128).

32. I am indebted to Theodore M. Porter, who raised "big" questions about a "little man" and the scientific profession, Karl Pearson, esp. Intro., Ch. 1, p.6. 
The first involves the literary biographies of women writers who have deepened my understanding of women's rights and feminism. ${ }^{33}$ The second touches on two female economists who have theorized about business, firms, or capitalism. ${ }^{34}$

Among the literary figures, Mary Wollstonecraft changed how I thought about almost everything. She penned $A$ Vindication of the Rights of Men in 1791, twenty-eight days after Edmund Burke published Reflections on the French Revolution. Without divulging her identity, she critiqued Burke's philosophical and moral stance. Critics applauded resoundingly. When she attached her female name to the second edition in 1792, however, many of the same critics did an about-face. They savaged a book that had previously won their acclaim, and bestowed upon Wollstonecraft a new identity:

33. Why literary biographies in particular? They stir the imagination! Sarah Tindal Kareem, Eighteenth-Century Fiction And The Reinvention Of Wonder (New York: Oxford University Press, 2015), and Melissa Sodeman, Sentimental Memorials: Women and the Novel in Literary History (Palo Alto, CA: Stanford University Press, 2015). Used judiciously, they provide a valuable source of information about women's roles and perspectives on economic institutions, including the family, the market, wealth, education, inheritance, networks, and firms. Literary histories engage the study of occupation and identity in ways that sew links to culture, encouraging interventions into gendered discourses that are not always available in sources customarily tapped by business and economic histories. See in particular, Thomas Piketty's use of Jane Austen's novels to provide information about wealth and inheritance, Capital in the Twenty-First Century (Cambridge, MA, and London: Belknap Press of Harvard University Press, 2014), 2, 53-54, 105-106, 241, 411-412, 415-416. For select feminist economist critiques, see Kathleen Geier, Kate Bahn, Joelle Gamble, Zillah Eisenstein and Heather Boushey, "How Gender Changes Piketty's 'Capital in the Twenty-First Century,"” http://www.thenation. com/blog/180895/how-gender-changes-pikettys-capital-twenty-first...10/14/2014; Diane Perrons, "Gendering Inequality: A Note on Piketty's Capital in the TwentyFirst Century,” British Journal of Sociology 65, no. 4 (2014) (doi: 10.1111/14684446.12114), 668-677). Historical scholarship that taps literary-minded business women include, Susan Coultlrap-McQuin, Doing Literary Business; American Women Writers in the Nineteenth Century (Chapel Hill and London: University of North Carolina Press, 1990); Susan Albertine, ed., A Living of Words: American Women in Print Culture (Knoxville: University of Tennessee Press, 1995); Mary Poovey, Uneven Developments: The Ideological Work of Gender in Mid-Victorian England (Chicago: University of Chicago Press, 1988), and The Proper Lady and the Woman Writer: Ideology as Style in the Works of Mary Wollstonecraft, Mary Shelley, and Jane Austen (Chicago and London: University of Chicago Press, 1984).

34. Why academic economists? Given that business and economic history are orphaned offshoots of two different mainstream disciplines, economics and history, both of which historically have been male-dominated, women have been notable by their absence. I am WOMAN. I began to ask: Where are the women? Who are they? What are their contributions to theories of the firm and capitalism? How has the profession valued them and their scholarship? How do we account for the results?

Since the 1970s, biographies of women political and business leaders have multiplied. I myself have linked the economic biographies of two women of overlapping generations, each of whom made pioneering contributions to business and economic history. However, in preparing this address, I grappled with a 
dangerous radical. Emboldened, she produced a sequel: $A$ Vindication of the Rights of Woman. ${ }^{35}$

Wollstonecraft's words about the "woman question" became a critical touchstone in the early battle for social justice. By connecting the condition of women to the distribution of wealth and power, she did for women what neither Karl Marx nor Thomas Piketty chose to do: She implicated capitalism and the men who had engineered it in the subjugation of women. She also tightened her talons around business. Alone with a young daughter, and disdainful of the institution of marriage, she hurled a critique against business and the pursuit of wealth. Her screed's hidden agenda was to shame Gilbert Imlay, her businessman mate, to stop his philandering and return home. The attempt failed, but her passionate cri de coeur still resonates. ${ }^{36}$

Wollstonecraft wanted to challenge the way of the world, to change everything that kept her from being what she wanted to be. She took on an ever-expanding set of obstacles-the state, religion, patriarchy, marriage, motherhood, and anyone who accepted the institutions that compromised and constrained individual freedom and free love. Her ideas about equality, feminism, and freedom were targeted at educated middle-class English men and women. The smart ones listened.

somewhat different challenge: how to weave autobiographical details relevant to my own self-making as a business historian together with a collective history of particular women professionals, each of whom excelled and experienced disappointments in different aspects of their personal and professional lives. A source of inspiration and education is Jill Ker Conway, The Road from Coorain (New York: Alfred A. Knopf, Inc., 1989), True North: A Memoir (New York: Alfred A. Knopf, Inc., 1994) , When Memory Speaks: Exploring the Art of Autobiography (New York: Alfred A. Knopf, Inc., 1998), and A Woman's Education (New York: Alfred A. Knopf, Random House, 2001).

35. Much of the Wollstonecraft material that follows is taken from Charlotte Gordon, Romantic Outlaws: The Extraordinary Lives of Mary Wollstonecraft and Her Daughter Mary Shelley (New York: Random House, 2015). The literature on both women is vast, but among the most significant is the following: Sue Ferguson, "The Radical Ideas of Mary Wollstonecraft," Canadian Journal of Political Science Vol. 32, Issue 03 (Sept. 1999): 427-450 (http://dx.doi.org/ 10.1017/S0008423900013913).

36. Gordon, 341. Business reaped the scorn that Wollstonecraft could not direct at her partner, Imlay. See also, Letters... in The Complete Works of Mary Wollstonecraft (Kindle edition). Wollstonecraft not only broke the male monopoly on travel writing, but also offered a critique of war (Letter 3, Loc 7014-7018 of 16314), the French Revolution (Letter 3, Loc 7025 of 1634-Loc 7035 of 16314), of business and business interests, mercantilism, and the pursuit of wealth. She purred with pride when a supper host told her bluntly, that she was a "woman of observation." She had asked him "Men's Questions" (Letter 1: Loc 6870 of 16314). She singled out commerce, property, and speculation as the root of many evils. Commerce, she complained, consumed time and sentiments (Letter X, 9017, 9489, 9729 of 16314, Letter XIII, Loc 8145, 8976, of 16314, Letter XXXII, Loc 10110 of 16314). She compared the systems of governance, the towns, the infrastructure, 
Wollstonecraft's jibes at business were grounded as much in moral as economic considerations at a time when other (mostly male) thinkers were itching to understand a new kind of free-market-oriented industrializing capitalism. To Mary, business was important only to the extent that it affected the well-being of those she loved. She died soon after she gave birth to her daughter Mary Shelley, who, in turn, gave literary birth to the Frankenstein monster, a rampaging male marauder who stalked the land during the Industrial Revolution. ${ }^{37}$

Wollstonecraft did not speak for all women. Nor did she succeed in changing everything. But she stirred radical conversations about sexual inequality and human rights and boldly pushed the discourse about women and equality into the public sphere. By giving birth as an unwed woman to a daughter whose own life had a revolutionary impact, Wollstonecraft ensured her own contested legacy. Two Marys, linked by biology, wrote an early chapter of a history created by women and for women. Between the lines, we can glimpse the future of business history—changing.

I arrived two centuries after those other two Marys, but even in my own era I came late to feminism. I was a business historian of manly industries such as meat packing and steel, whose mentor had

and the work and domestic habits of various classes she observed as she moved across northern Europe. In A Vindication of the Rights of Men: Reply to Burke's Reflections on the French Revolution (The Complete Works...[Kindle ed.]), she complained that "the demon of property has ever been at hand to encroach on the sacred rights of men, and to fence round with awful pomp laws that war with justice" (Loc 109 of 16314). She considered Burke's defense of American independence indefensible, as it accepted "slavery on an everlasting foundation." She regarded the English definition of liberty, linked as it was to security of property, as a "selfish principle" to which "every nobler one is sacrificed" (Loc 224 of 16314).

37. Mary Shelley's attitudes about business were shaped by her own lack of funds and financial support and by the inequality of income and wealth she observed, as well as her response to traveling companions, conditions, and climate. She showed concern with her own sales figures and reputation, as well as society's strictures, which required women to be self-effacing in the face of literary success. Her battles over inheritance stemmed from her father's disapproval of her alliance with the poet Shelley (Gordon, 107, 211, 531).

The literature about Mary Shelley is almost as vast as that which analyzes the creature she created, but business historians have left to literary lights the task of harnessing the monster to the Industrial Revolution. See how Thomas Pynchon plots the journey from Frankenstein to modern-day robots: "Is It O.K. to Be a Luddite?" New York Times on the Web, October 28, 1984 (https://www.nytimes. com/books/97/05/18/reviews/pynchon-ludd...Accessed 10/7/2015). See Emily W. Sunstein's review of Mary Shelley: Her Life, Her Fiction, Her Monsters by Anne K. Mellor, Keats-Shelley Journal 39 (1990): 207-210; Charlotte Sussman, "Daughter of the Revolution: Mary Shelley in Our Times," Journal for Early Modern Cultural Studies, Vol. 4, No. 1, Women Writers of the Eighteenth Century, (Spring/Summer), pp. 158-186, http://www.jstor.org/stable/27793781; Stephanie S. Haddad, Economist, 2 , no. 1 (2010), 1, examines some of Shelley's other writings. "Though all of the 
privileged cost over sex differentials. As such, I felt I was Mary-comelately to the feminist sisterhood. Early in my academic career, I did not understand feminist organizing strategies and theories and I wasn't sure I should care. I published an article called "Will There Ever Be a Feminist Business History?” but I did not provide a definitive answer to my own question. The piece echoed questions that had been asked years earlier by female scholars in women's history and the associated disciplines of sociology and economics. I used "feminist" as an identifier for what I hoped might become a new type of business history, written by women for both women and men-a business history of their own. ${ }^{38}$

I figured, who better than feminists? Their gender claws had been sharpened by a world dominated by men, and by firms and businesses dominated, in turn, by the male sex. I regarded the opportunities for gender analysis as wide-ranging, covering both men and women in business, and encompassing a whole spectrum of races and ethnicities.

But this Yeager brand of business feminism was tepid by the social justice standards of seasoned feminists. Swedish writer Anita Goransson, surveying gendered property rights, pulled no punches: The firm was "a bourgeois front organization dominated and controlled

female characters mentioned were created by a female author, each of them has a very demeaning characterization. Shelley's women are objectified, used, abused, and easily discarded. None of them, save Margaret, survive the novel and all of them live their fictional lives to serve a very specific function and impact a man's life."

38. Mary A. Yeager, "Lessons from Al, Revisited," Business History Review 82.2 (Summer 2008): 309-311. One consequence of my disciplinary training in business and economic history is that when I began to investigate the history of women, I continued to embrace "the firm" as a basic analytical category and to stress interactions and intersections between and among women and men in business and economies. Angel Kwolek-Folland's pioneering Incorporating Women: A History of Women and Business in the United States (New York: Twayne Publishers, 1998) used a different strategy, reflecting a disciplinary background in women and cultural history. Her foray into business preceded this synthesis and engaged architecture as well as social history and the history of gender. My introduction to Kwolek-Folland came through an editor for the of Johns Hopkins Press, Robert Brugger, who invited me to review the manuscript that became Engendering Business: Men and Women in the Corporate Office (Baltimore: Johns Hopkins University Press, 1994). About the same time, Geoffrey Jones, series editor for the International Library of Critical Writings in Business History, invited me to assemble a collection of articles for a volume on women in business, which became Women In Business, 3 vols. (Cheltenham, UK and Northampton, MA, USA: The International Library of Critical Writings in Business History 17, Edward Elgar Publishing, Inc., 1999). Vol. 1 included my lengthy introduction and overview, ix-xciii, and "Will There Ever Be a Feminist Business History?," 3-45, The bibliography in Vol. 1 combines the most significant publications about women and business in the literature of economics, business and economic history, gender and women's history. 
by men to exclude women." She asked a question that stopped me in my tracks: "Could it be that there exists a systematical relationship between gender and economic power-historically as well as today?"39

Frozen in place, I had no answer. I had the inclination, but I needed to regroup. I was a business historian, not a feminist activist jumping on the barricades. But I had begun to listen to other women's ideas about business and capitalism, and I'd begun to ask my own questions about the business interactions between women and men. ${ }^{40}$

Feminists, I found, were hardly a cohesive bunch, either in terms of their own identities or the issues that they prioritized. The one thing they agreed on was women's devaluation in cultures and economies. If earlier, first-wave feminists targeted capitalism and patriarchy as dual oppressors of women, second-wave successors moved toward questions of recognition. Women's identities as women began to matter in new ways as multiculturalism took hold.

The analytical tools associated with the triad of gender, race, and ethnicity arrived late to business history, just as the field was in the throes of its own deconstruction project. Subdisciplines were sprouting up devoted to small businesses, specialty manufacturing, black enterprise, and ethnic minorities. For a brief revolutionary moment, business historians made an end run around the economy to engage "culture" in a scramble for the meaning of business. The Chandlerian paradigm was in disarray, leaving the detritus of economics in its wake and paving the way for the re-entry of business into society. ${ }^{41}$

39. Yeager, Women in Business, Vol. 1, quoting Anita Goransson, "Gender and Property Rights: Capital, Kin, and Owner Influence in Nineteenth- and TwentiethCentury Sweden," 283, 273.

40. Among them were many big questions inspired by a handful of intellectual historians and most female moral philosophers: "How do we understand capitalismpast and present-as both an economic system and a form of life?" (Nancy Fraser and Mary Midgley); "Where does women's oppression come from? From men? From capitalists? Or the system? How do feminist writers explain the relationship between capitalism and the condition of women? (Nancy Fraser); What is a "feminist issue" and how has it been defined and framed in business history? In what spaces and where do women find their voices in business history? (Daniel Horowitz, "Feminism, Women's History, and American Social Thought...”); Why do business historians want to put capitalism in the foreground now? What are the consequences for the study of women, gender, and business? Given that structures of inequality have assumed the most internalized forms-as in genderdo women have any real choices, other than trying to understand men? (David Graeber, Utopian Rules); Why has the women's movement and feminism played such a minor footnote in dominant narratives of business history? Why has business played such a minor role in the history of feminism? (Sarah M. Evans, "Sons, Daughters and Patriarchy: Gender and the 1968 Generation," and "Women's Liberation,"; Glenna Matthews, Silicon Valley, Women, and the California Dream).

41. This necessarily brief synthesis builds on Nancy Cott, "What's in a Name? The Limits of 'Social Feminism;' or, Expanding the Vocabulary of Women's History," 
Concurrently, my life was undergoing its own deconstruction, albeit a joyful one. My waltz with feminism and capitalism coincided with the jubilant embrace of motherhood and a calamitous professional reckoning. Who had constructed these promotional ladders? And for whom? There was no pause in the tenure clock, no downtime, no maternity or paternity leave. A solicitous male colleague suggested that better planning might help. He himself had contrived that his wife should deliver their babies in the summer months, to minimize his teaching burdens. ${ }^{42}$

Where was Mary Wollstonecraft when I needed her?

The two Marys, of course, did not formally belong to a card-carrying profession. Like other literary women of their era, they wrote to survive economically at a time when few other occupational alternatives

Journal of American History 76, no. 3 (1989): 809-929; Sarah M. Evans, "Women's Liberation: Seeing the Revolution Clearly,” Feminist Studies 41, no. 1 (2015): 138149 (http://www.jstor.org/stablw/10.15767/feministstudies.41.1.138, accessed 5/18/2015), and Sara M. Evans, "Sons, Daughters, and Patriarchy: Gender and the 1968 Generation,” AHR Forum: The International 1968, Part II, American Historical Review 114, no. 2 (2009): 331-347 (doi:10.1086/ahr.114.2.331, accessed 9/6/2015); Laurie Penny, Unpeakable Things: Sex, Lies And Revolution (New York: Bloomsbury, Kindle edition, 2014); Cynthia Enloe, The Curious Feminist: Searching for Women in a New Age of Empire (Berkeley, Los Angeles, London: University of California Press, 2004); Sherry B. Ortner, “Too Soon for Post-Feminism: The Ongoing Life of Patriarchy in Neoliberal America," History and Anthropology, 2014 (http://DX. DOI.ORG/10.1080/02757206.2014.930458), "Subjectivity and Cultural Critique," Anthropological Theory 5, no. 1 (2005), 31-52 (doi: 10.1177/1463499605050867, accessed, ant.sagepub.com at ucla, 1/23/2015), Making Gender: The Politics and Erotics of Culture (Boston: Beacon Press, 1996), Anthropology and Social Theory: Culture, Power and the Acting Subject (Durham, NC and London: Duke University Press, 2006); Melissa S. Fisher, Wall Street Women (Durham, NC and London: Duke University Press, 2012); Mary Midgley, Are You an Illusion? (Durham, NC: Acumen Publishing Limited, 2014); David Midgley, ed. The Essential Mary Midgley (London and New York: Routledge, 2005); Mary Midgley and Judith Hughes, Women's Choices: Philosophical Problems Facing Feminism (London: Weidenfeld and Nicolson, 1983); Eva Tutchell and John Edmonds, Man-Made: Why So Few Women Are in Positions of Power (Surrey, England and Burlington, VT: Gower Publishing Company, 2015); Nancy Fraser, "Feminism, Capitalism, and the Cunning of History: An Introduction,” Working Paper Series No. 17, Fondation Maison des sciences de l'homme (FMSG), Le College d' etudes mondiales, (August 2012): 1-14 (http://www.msh-paris.fr-FMSH-WP-2012-17); Daniel Horowitz, "Feminism, Women's History, and American Social Thought at Midcentury," in Nelson Lichetenstein, ed., American Capitalism: Social Thought and Political Economy in the Twentieth Century (Philadelphia: University of Pennsylvania Press, 2006), 191-209; Sven Beckert, "History of American Capitalism," Ch. 14, and Rebecca Edwards, "Women's and Gender History," Ch. 15, in American History Now, Eric Foner and Lisa McGirr, eds. (Philadelphia: Temple University Press, Kindle edition, 2011); Howard Brick, Transcending Capitalism: Visions of a New Society in Modern American Thought (Ithaca, NY and London: Cornell University Press, 2015).

42. The most helpful interpretation and analysis of the predicament that some academic women find themselves in with regard to promotional ladders and gender 
were available to them. They associated with white middle-class writers, secured male publishers to disseminate their work, and achieved hard-won recognition of their claim to professional status.

By the twentieth century, it was a good deal easier to make such a claim. But challenges remained. As a young scholar navigating the two male-dominated sub-disciplines of business and economic history, I ran across the writings of a number of female professionals who demonstrated that when women theorize, things change. ${ }^{43}$

Charlotte Perkins Gilman was a self-taught, uncredentialed sociologist, writing around the turn of the century. Gilman fearlessly placed the root of women's subordination at the intersection of sexuality and economics. She wanted to run with the big boys instead of staying home with husband and kids. In a piece called "Aunt Mary's Pie Plant," she offered a hopeful parable of a woman succeeding in small business. It was a trifle, but a pungent one. Far more ambitious was her Women and Economics, a weightier theorizing project that injected feminine values into the social and economic life of her day. ${ }^{44}$

Miriam Beard, writing as a professional outsider and "amateur historian," offered the first ever global history of the businessman, just as war clouds were gathering in the late 1930s. She threw a literary lifeline to this beleaguered male figure, not forgetting the women and wives who played critical roles in everyday capitalism. She listed as many businesspeople as she could find, portraying all of them as struggling mightily to steer American capitalism away from the forces of fascism and totalitarianism. Few professionals paid much attention.

A few decades later, in the stacks of the Harvard Business School, I met a woman who gave me the courage to be myself. Her work stirred

schemas at work is sociologist Virginia Valian, Why So Slow? (Boston: MIT Press, paperback ed., 1999). See also Sylvia Ann Hewlett, Off-Ramps and on Ramps: Keeping Talented Women on the Road to Success (Boston: Harvard Business School Press, 2007); Alice H. Eagly and Linda L. Carli, Through the Labyrith: The Truth about How Women Become Leaders (Boston: Harvard Business School Press, 2007). For a superbly powerful recent critique of contemporary, bureaucratized capitalism as well as academia and the professions, see anarchist/anthropologist David Graeber's The Utopia of Rules: On Technology, Stupidity, and the Secret Joys of Bureaucracy (Brooklyn, NY: Melville House Publishing, 2015).

43. Mary A. Yeager, "Everywoman's Entrepreneur: Five Women Consider The Fourth Factor of Production," paper presented at the International Conference on Entrepreneurship in Theory and History, Department of Economics, Athens University of Economics and Business, Athens, European Cultural Center, Delphi, Greece, June 13-16, 2002. Unpublished conference paper, in author's possession.

44. Ibid. The literature on Gilman is vast, with scholars of English literature and poetry, culture, and feminism far outnumbering economic and business historians. Of the latter, economic historians have shown more interest than business historians. Carol Farley Kessler, Charlotte Perkins Gilman: Her Progress Toward 
me to write about business and educational institutions in a way that illuminated their rules, power, and unequal hierarchies. Her name was Henrietta Larson. Larson was a farm girl from Minnesota, a declared Republican, and the author, co-author, and editor of numerous books and articles. Most notably, she edited an authoritative three-volume history of Standard Oil of New Jersey. Newsweek christened her "The Iron Lady of the Harvard Business School.” The men at Standard Oil adored her. She adored them. Harvard tenured her twenty-eight years after she arrived and a year before she retired. This made her the first tenured female professor at Harvard Business School. It was 1962, the same year Harvard Business School admitted its first seven female MBA students. ${ }^{45}$

Utopia with Selected Writings (Syracuse, NY: Syracuse Univ. Press, 1995), 117-129, includes “Aunt Mary's Pie Plant [1906],"; Carl Degler, ed., Women and Economics: A Study of the Economic Relation between Men and Women As a Factor in Society by Charlotte Perkins Gilman (Boston: Small, Maynard \& Company, 1898; New York: Harper Torchbook ed., Harper \& Row, Publishers, 1966); Charlotte Perkins Gilman, Herland (New York: Pantheon Books, Random House, 1979); Ann J. Lane, ed., The Charlotte Perkins Gilman Reader (Charlottesville and London: 1st University of Virginia Press ed., 1999); Sheryl L. Meyering, ed., Charlotte Perkins Gilman: The Woman and Her Work (Ann Arbor, MI: UMI Research Press, 1989); Falguni A. Sheth and Robert E. Prasch, "Charlotte Perkins Gilman: Reassessing Her Significance for Feminism and Social Economics," Review of Social Economy 44, no. 3 (1996): 323-337; Margaret G. O’Donnell, "A Reply to 'Charlotte Perkins Gilman: Reassessing Her Significance for Feminism and Social Economics," Review of Social Economy 44, no. 3 (1996): 337-341; Jennifer Hudak, "The Social Inventor: Charlotte Perkins Gilman and the (Re) Production of Perfection," Women's Studies 32, no. 4 (2003): 455-477; Li-Wen Chang, "Economics, Evolution, and Feminism in Charlotte Perkins Gilman's Utopian Fiction," Women's Studies: An Interdisciplinary Journal 39, no. 4 (2010): 319-348 (http://dx.doi.org/ 10.1080/00497871003661711), accessed 8/22/2015.

45. Mary A. Yeager, "Mavericks and Mavens of Business History: Miriam Beard and Henrietta Larson," Enterprise and Society, 2, no. 4 (2001): 687-768. See also Henrietta Larson, Larson Family Archives, St. Olaf, Northfield, MN. Larson argued that "business is what society makes it." She insisted, "Business history is not a one time discovery ... it did not spring full blown from Professor Gras' brow." It was, she argued, "a study of process rather than description." She defined the field as the "study of the development and operation of that institution of society, in all its ramifications, which has as its function to provide goods and services for the market ... it deals with one of the basic institutions of modern times, comparable to school, church, or state." Long before the cultural turn in business history, she complained that business history "needs deepening and broadening. More rigorous analysis to seeing the large structure of relationships, to the search for significance or meaning. ... The historian is the memory, the interpreter, the conscience of the past; as such he is the teacher of the present and also something of a prophet, for he can do much to stimulate thinking and to create attitudes and feelings which have a part in molding the future. This implies that the historian at best may [detract or add to] the stature and expectations of business as a social institution." The experiences and the careers of male MBAs at Harvard are detailed in David Callahan, Kindred Spirits: Harvard Business School's Extraordinary Class of 
Biography was essential to the rediscovery and the repositioning of each of these professionals in business history. Their histories and visions inspired me at critical junctures in my own professionalization process. But none were more inspiring than two economists who, as women and as professionals, kept my mind focused on the big picture of economic change and development. ${ }^{46}$

Joan Robinson was born in Surrey, England, in 1903 to Sir Frederick and Helen Maurice, both Christian Socialists and independent

1949 and How They Transformed American Business, and those of women in Liz Roman Gallese, Women Like Us: What Is Happening to the Women of the Harvard Business School, Class of '75-The Women Who Had the First Chance to Make It to the Top (New York: William Morrow \& Co., Inc., 1985). For Stanford MBAs, see Myra Strober, “The MBA: Same Passport to Success for Women and Men?" in Women in the Workplace, edited by Phyllis Wallace, 25-44 (Boston: Auburn House Publishing Co., 1982); Mary Dingee Fillmore, Women MBAs: A Foot in the Door (Boston: G.K. Hall \& Co., 1987). For information about faculty, see Scaling the Ivory Tower: Stories from Women in Business School Faculties, ed. Dianne Cyr and Blaize Horner Reich (Westport, CT: Praeger, 1996). The classic study of the MBA is Carter A. Daniel, MBA: The First Century (Lewisburg, PA: Bucknell University Press, and London: Associated University Presses, 1998), whereas the best recent study of business schools is Rakesh Khurana, From Higher Aims to Hired Hands: The Social Transformation of American Business Schools and the Unfulfilled Promise of Management as a Profession (Princeton, NJ: Princeton University Press, 2007).

46. The professionals were Edith Penrose and Joan Robinson, both of whom I had met (Edith, at HBS/BHC conference in the early 1980s, and Joan, after a lecture at Harvard University in the late 1970s). Louis Galambos was one of the first business historians to single out the professions as a promising new field of research: "Technology, Political Economy, and Professionalization: Central Themes of the Organizational Synthesis," Business History Review 57, no. 4 (1983): 471-493, and "The Role of Professionals in the Chandler Paradigm," Industrial and Corporate Change (2010) 19(2): 377-398 (doi:10.1093/icc/dtq009). Notable by its absence from most studies of the professions is any mention of sex and gender. For feminist critiques of the professions, see Ann Witz, Professions and Patriarchy (New York: Routledge, Chapman and Hall, 1992); Nel Noddings, "Feminist Critiques in the Professions," Review of Research in Education 16 (1990): 393-424 (stable URL: http.//www.jstor.org/stable/1167357, accessed 6/9/2015). An early forerunner, but excluding business or management, is Penina Migdal Glazer and Miriam Slater, Unequal Colleagues: The Entrance of Women into the Professions, 1890-1940 (New Brunswick, NJ and London: Rutgers University Press, 1987); Athena Theodore, ed., The Professional Woman (Cambridge, MA: Schenkman Publishing Company, 1971).

A selective list of relevant publications about Joan M. Robinson and Edith Penrose, the two scholars discussed here, includes Ingrid H. Rima, ed., The Joan Robinson Legacy (Armonk, NY and London: M. W. Sharpe, 1991); Collected Economic Papers, 5 vols. (Cambridge, MA: MIT Press, 1980), especially I, 1-2, 8-9, 12-14, 14n., 17, and n. 19; 22; II, 227-227, xiii, 66; George R. Feiwel, ed., Joan Robinson and Modern Economic Theory 2 vols., (London: Macmillan Press Ltd., 1989); Marjorie S. Turner, Joan Robinson and the Americans (Armonk, NY and London: M.E. Sharpe, 1989); G. C. Harcourt, "Obituary: Joan Robinson 1903-1983," The Economic Journal 105, no. 432 (1995): 1228-1243; Paul A. Samuelson, "The Passing of the Guard in Economics,” Eastern Economic Journal 14, no. 4 (1988): 319-329 (http://www.jstor.org/ stable/40325232); Harvey Gram and Vivian Walsh, “Joan Robinson’s Economics in 
thinkers from distinguished families. One of four daughters in a family of five children, Robinson grew up adhering to a stern lesson learned at home: Say and do what is right, no matter what the consequences. She earned a degree in economics at St. Paul's and Girton, then moved on to Cambridge University in the mid-1920s. Once there, she joined a formidable cohort of male economists known as "the Cambridge circus," committed to modernizing economics. She cut her economic teeth on intellectual debates with the likes of John Maynard Keynes and Piero Saffra, exploiting the privileges of their network while building a professional identity unlike that of any other woman in economics. Nahid Aslanbeigui and Guy Oakes, in their innovative 2009 biography The Provocative Joan Robinson, place Joan in the same ring with these manly economists, boxing gloves on, testing her ideas against theirs within the confines of one of England's most elite institutions of higher learning. ${ }^{47}$ Along the way, she developed a dazzling writing style that leaped off the page. Listen to her vibrant literary voice as she tartly critiques the mainstream economic models of the 1930s:

Retrospect,” Journal of Economic Literature 21(1983): 518-550; G. C. Harcourt and Prue Kerr, Joan Robinson (New York: Palgrave Macmillan, 2009). For information on Penrose, I have relied on Christos Pitelis, ed., The Growth of the Firm: The Legacy of Edith Penrose (Oxford: Oxford University Press, 2002). Especially helpful are Michael Best and Jane Humphries, "Edith Penrose: A Feminist Economist?," Feminist Economics 9, no. 1 (2003): 47-73 (doi: 10.1080/1354570022000044436, http://dx.doi.org/10.1080/1354570022000044436); Brian J. Loasby, "The Significance of Penrose's Theory for the Development of Economics," Contributions to Political Economy 18 (1999): 31-45; Michael Best and E. Garnsey, "Edith Penrose, 1914-1996,” The Economic Journal (February 1999): 109; C. Matheson Connell, "Discerning a Mentor's Role: The Influence of Fritz Machlup on Edith Penrose and the Theory of the Growth of the Firm," Journal of Management History 13, no. 3 (2007): 228-239 (http://dx.doi.org/10.1108/17511340710754680); Simone T. A. Phipps, "Mary, Mary, Quite Contrary: In a Male-Dominated Field, Women Contributed by Bringing a Touch of Spirituality to Early Management Theory and Practice," Journal of Management History 17, no. 3 (2011): 270-281 (http:// dx.doi.org/10.1108/17511341111141350).

Edith Penrose, review of Joan Robinson, Aspects of Development and Underdevelopment (1979), The Economic Journal 90, no. 359 (1980): 623-625 (http:// www.jsotr.org/stable/2231933, accessed: 06/09/2015). Penrose cites Robinson's "refreshing lack of atrocious jargon," and admires her effort to communicate to a broader audience. She also praises Robinson for stressing the importance of social relations, legal and property rights, and the role of power of the state in economic development. She applauds her effort to take a holistic view of political economy, but criticizes her "selective" use of examples, which, she complains, "suits her points." She concludes by contrasting her own position with that of Robinson, saying that she does not want to lose the "good" in capitalism merely to attack it.

47. Nahid Aslanbeigui and Guy Oakes, The Provocative Joan Robinson: The Making of a Cambridge Economist (Durham, NC and London: Duke University Press, 2009). 
Nothing much is usually said about the inhabitants of the model. The ancestry of Adam Smith is often claimed for it, but his world was inhabited by workers, employers, and gentlemen. Here there are only transactors or economic subjects ... the people in this model are like the conventionally invisible propertymen of the Kabuki theater, and only the commodities have speaking parts. ${ }^{48}$

As Joan's biographers describe it, 1920s Cambridge "had a long and inglorious history of discrimination against women unique among British universities." But, Joan, in their words, viewed economic theory as "an androgynous enterprise," and "her work transcended differences of gender." In that biased environment, she survived. She married Austin Robinson, a network man who provided her with financial security, and she concentrated on ideas. ${ }^{49}$ Although she bore two daughters and played hostess to relatives and friends, her priorities were immutable. "I find intensive family life quite amusing," she wrote, "but I can see it wouldn't suit me for an occupation." She kept on debating and writing, producing a string of publications and pulling herself up the promotional ladder. In 1931, she earned an appointment as an assistant lecturer and, after six more years, a lectureship. At least nine books and hundreds of reviews later, she finally won a full professorship in $1965 .^{50}$

But despite her stunning achievements, Joan Robinson's life and career were far from trouble-free and, for me, her struggles tell a cautionary tale. She was drained by combative intellectual jousting in an environment that advantaged men over women. She was unable to manage marital strains, complicated by an extramarital fling with another network economist. She was gravely alarmed by an impending arms race far beyond her powers to fix. Overwhelmed by such emotional strife, she succumbed three times to nervous collapse.

48. Robinson, "What are the Questions?", in Joan Robinson, Collected Economic Papers, Vol. 5 (Boston, Mass: MIT Press, 1st ed. 1980), 5. Robinson was adamant that the discipline of economics was distinguished only by its "tool box," which she applied as a way into understanding the problems of the real world.

49. Aslanbeigui and Oakes, 25, 4. One consequence of the attention paid to Joan Robinson has been the neglect of the scholarly contributions of her husband, Austin. Some have begun to notice. Lowell Jacobsen, "On Robinson, Penrose, and the Resource-Based View," European Journal of History of Economic Thought, 20, no. 1 (2013): 124-147 (htt;//dx.doi.org/10.1080/09672567.2011.565355). Curiously, few have asked what Austin and Joan talked about. Did each assist the other, in terms of publishing, theorizing efforts? What do their children remember about their relationship and interaction as scholars?

50. Aslanbeigui and Oakes, 155. Luigi L. Pasinetti, Keynes and the Cambridge Keynsians: A 'Revolution in Economics' to be Accomplished (Cambridge, and New York: Cambridge University Press, 2007), 97, notes that Joan became a full professor “only on Austin Robinson's retirement in 1965." 
An academic disappointment was less harrowing but just as poignant. Professional gossip had led Joan to expect the Nobel Prize for her massively impressive set of publications. She was denied it. Year after year, laureates were named whose work she considered no more important than hers. She was stung by the slight but feigned not to care.

By most standards, the Joan Robinson biography is a tale of triumph-but her struggles resonate. One can rationalize power imbalance and inequality as the just products of merit, effort, or talent, but too often, something else is at work. I happen to agree with those scholars who believe that a profession that disadvantages women more than men is a profession in trouble and in need of change.

Let me end with one last anecdotal snippet from my own biography. This one involves a brief encounter with a second female economic giant. It took place in the early 1980s, when I attended one of the annual meetings of our organization at the Harvard Business School. A plenary session of that conference featured a panel whose topic was business historians who stood "On the Shoulders of Giants." Perhaps not surprisingly, all the panelists and all their subjects were men. The mostly male audience listened intently.

Halfway through the proceedings, I had had enough. I could not contain the Yeager Grumble. I stood up and challenged the panel with a rapid fire volley of questions: "Have no women ever stood on male shoulders? Are there no female shoulders to stand on? What about female theorists of industrial organization? Imperfect competition? The growth of the firm? Come on, guys! What about female candidates for the Nobel Prize?"

The panelists fell silent for a moment. They looked at each other, peeved and perplexed. Finally, as if on cue, they flashed big smiles and spoke the only name that came to mind, and only after considerable thought: "Why, Joan Robinson, of course!"

Minutes later, as the panel wrapped up and the audience headed for the exits, I spotted a familiar figure who had attended the session seated next to my mentor, Al Chandler. It was Edith Penrose, the revered economist and theorist of the firm. She caught my eye, smiled, and gave me a conspiratorial wink. "Honey," she said, "do you think you will change anyone's mind?"

Well, Edith, I've been trying ever since. Women don't change everything. But given time, they change a lot. 